\title{
Effect of Activins AB and B on DNA Synthesis Stimulated by Epidermal Growth Factor in Primary Cultured Rat Hepatocytes
}

\author{
Shingo NiImI, ${ }^{* a}$ Mai HoriKawa, ${ }^{b}$ Taiichiro Seri, ${ }^{b}$ Toyohiko Ariga,,${ }^{b}$ Tetsu Kobayashi, ${ }^{a}$ and \\ Takao HAYAKAWA ${ }^{a}$ \\ Division of Biological Chemistry and Biologicals, National Institute of Health Sciences, ${ }^{a}$ 1-18-1 Kamiyoga Setagaya-ku, \\ Tokyo 158-8501, Japan and Department of Nutrition and Physiology, Nihon College of Bioresource Sciences, ${ }^{b}$ Kameino \\ Fujisawa 252-8510, Japan. Received October 16, 2001; accepted January 12, 2002
}

\begin{abstract}
The effect of activins AB and B on DNA synthesis stimulated by epidermal growth factor (EGF) was studied in primary cultured rat hepatocytes and compared with the effect of activin A, a suppressor of DNA synthesis. Activin AB inhibited DNA synthesis as assessed by $\left[{ }^{3} \mathrm{H}\right]$ thymidine incorporation. The inhibition by activin $A B$ was detected at $6 \mathrm{ng} / \mathrm{ml}$, and the $12.5 \mathrm{ng} / \mathrm{ml}$ concentration produced almost maximal inhibition, approximately $40 \%$, almost the same as that produced by activin A. Inhibition by activin A was detected at $3 \mathrm{ng} / \mathrm{ml}$, and the $6 \mathrm{ng} / \mathrm{ml}$ concentration produced almost maximal inhibition. Activin B, on the other hand, had no effect on DNA synthesis up to $50 \mathrm{ng} / \mathrm{ml}$. The increase in labeling index by EGF was also reduced to about $20 \%$ by $25 \mathrm{ng} / \mathrm{ml} \mathrm{ac-}$ tivin $A$ and activin AB, but not by activin B. Activin B, however, inhibited the binding of $\left[{ }^{125} I\right]$ activin A to hepatocytes, but had no effect on the inhibition of DNA synthesis by activin A, even at 3-fold excess concentrations. These findings suggest that activin AB may act in the same manner as activin A does in terms EGF's inhibitory effect on DNA synthesis, although the effective concentration is higher than that of activin A. The findings also suggest that activin $B$ receptors are present in hepatocytes but that they do not mediate signal transduction leading to the inhibition of DNA synthesis.
\end{abstract}

Key words activin; cultured rat hepatocyte; DNA synthesis; epidermal growth factor (EGF)

Activins are members of the transforming growth factor- $\beta$ superfamily and are homodimeric proteins composed of two inhibin/activin $\beta$-subunits linked by a disulfide bridge. ${ }^{1-5)}$ Four $\beta$-subunits have been identified in mammals thus far: $\beta_{\mathrm{A}}, \beta_{\mathrm{B}}, \beta_{\mathrm{C}}$, and $\beta_{\mathrm{E}}$. Of all of the dimer that are theoretically possible, only activin $\mathrm{A}\left(\beta_{\mathrm{A}}, \beta_{\mathrm{A}}\right)$, activin $\mathrm{AB}\left(\beta_{\mathrm{A}}, \beta_{\mathrm{B}}\right)$, activin $\mathrm{B}\left(\beta_{\mathrm{B}}, \beta_{\mathrm{B}}\right)$ and activin $\mathrm{C}\left(\beta_{\mathrm{C}}, \beta_{\mathrm{C}}\right)$ have actually been isolated. $^{6-11)}$

Activin was originally identified as a stimulator of FSH (follicle-stimulating hormone) secretion. ${ }^{6-8)}$ Later, activins were shown to be expressed in various organs during development and in acquired conditions, and to have a wide variety of biological functions, including regulation of cell proliferation and differentiation, and induction of mesodermal tissues during amphibian development. ${ }^{12,13)}$

Recent studies have shown that activin A plays several roles in rat liver in vivo and in vitro. ${ }^{13-17)}$ It inhibits mitogeninduced DNA synthesis in vitro, ${ }^{14)}$ induces hepatocellular apoptosis in vivo and vitro, ${ }^{15-17)}$ and stimulates glycogenolysis in vitro. ${ }^{18)}$ Activin $\mathrm{C}$ has been reported to have no effect on DNA synthesis by liver tumor cell line HepG2. ${ }^{11)}$ However, there have been no reports on the actions of activin $\mathrm{AB}$ and $\mathrm{B}$ in rat liver either in vivo or in vitro. It, therefore, seemed meaningful to examine the effect of activins $A B$ and $\mathrm{B}$ on the liver functions that have been shown to be regulated by activin A. In this regard, we were especially interested in mitogen-stimulated DNA synthesis as a model system for its biological significance, because expression of $\beta_{\mathrm{A}}$ and $\beta_{\mathrm{B}}$ mRNA in rat liver has been found to change markedly in rat models of liver regeneration. ${ }^{14,19)}$ In this paper, we examined the effect of activins $\mathrm{AB}$ and $\mathrm{B}$ on DNA synthesis stimulated by epidermal growth factor (EGF) in primary cultured rat hepatocytes and compared their effect with that of activin A.

\section{MATERIALS AND METHODS}

Materials The materials used for cell isolation and cell culture were the same as reported by Tanaka et al. ${ }^{20)}$ Recombinant human (rh) activin A was kindly provided by Dr. Y. Eto (Ajinomoto Co., Inc., Japan). Porcine activin A, activin $\mathrm{AB}$, and activin $\mathrm{B}$ were purchased from Wako (Osaka, Japan). EGF was obtained from Toyobo (Osaka). $\left[{ }^{3} \mathrm{H}\right]$ thymidine $(89.9 \mathrm{Ci} / \mathrm{mmol})$ was purchased from NEN Life Science Products (Boston, MA, U.S.A.).

Cell Isolation and Monolayer Culture Parenchymal hepatocytes were isolated from adult male Wistar strain rats weighing $180-200 \mathrm{~g}$ by in situ perfusion of the liver with collagenase ${ }^{20)}$ and they were suspended, $2 \times 10^{5}$ cells $/ \mathrm{ml}$, in Williams' E medium containing $5 \%$ fetal bovine serum, $10 \mathrm{~nm}$ insulin, and $1 \mathrm{~nm}$ dexamethasone, and cultured at $0.2 \times 10^{5} \mathrm{cells} / \mathrm{cm}^{2}$ in a 48 -well and 6-well microplate (IWAKI) precoated with collagen type-1 $\mathrm{AC}$ in a humidified chamber at $37^{\circ} \mathrm{C}$ under $5 \% \mathrm{CO}_{2}$ and $30 \% \mathrm{O}_{2}$ in air. Cells plated in the 48-well and 6-well plate were used to measure DNA synthesis and $\left[{ }^{125} \mathrm{I}\right] \mathrm{rh}$ activin A binding, respectively. After $2.5 \mathrm{~h}$, the medium was replaced with serum- and hormone-free medium containing aprotinin $(1 \mu \mathrm{g} / \mathrm{ml})$.

Measurement of $\left[{ }^{3} \mathrm{H}\right]$ thymidine Incorporation After $15 \mathrm{~h}$, the medium was replaced with hormone-free medium containing aprotinin $(1 \mu \mathrm{g} / \mathrm{ml})$ and $0.1 \%$ bovine serum albu$\min (\mathrm{BSA})$, and various hormones were added. After another $24 \mathrm{~h},\left[{ }^{3} \mathrm{H}\right]$ thymidine $(0.626 \mu \mathrm{Ci})$ and thymidine $(67.6 \mathrm{ng})$ were added, and $10 \mu \mathrm{g} / \mathrm{ml}$ aphidicolin was added at the same time. $\left[{ }^{3} \mathrm{H}\right]$ thymidine incorporation was measured by a modification of the method of Takai et al. ${ }^{21)}$ After $24 \mathrm{~h}$, the cells were washed twice with cold phosphate-buffered saline and fixed with $0.25 \mathrm{ml}$ of $10 \%$ trichloroacetic acid (TCA) overnight. The hepatocytes were solubilized in $0.25 \mathrm{ml}$ of $1 \mathrm{~N}$ $\mathrm{NaOH}$ at $37^{\circ} \mathrm{C}$ for $1 \mathrm{~h}$, and $0.1 \mathrm{ml}$ of the solution was re- 
moved for protein assay. The rest of the solution was mixed with $0.65 \mathrm{ml}$ of $1 \mathrm{~N} \mathrm{NaOH}, 12.8 \mu \mathrm{l}$ of bovine serum albumin $(10 \mathrm{mg} / \mathrm{ml})$, and then $0.2 \mathrm{ml}$ of $100 \%$ TCA. The precipitate was washed with $10 \%$ TCA, and the DNA was hydrolyzed by heating the precipitate at $100^{\circ} \mathrm{C}$ for $15 \mathrm{~min}$ in $1.0 \mathrm{ml}$ of $10 \%$ TCA. The difference between the radioactivity in the hot-TCA soluble fraction with and without aphidicolin was calculated as dpm/mg protein, and the values were subtracted from the control value, and divided by the value from cells treated with EGF, and they are shown as percentages of $\left[{ }^{3} \mathrm{H}\right]$ thymidine incorporation. Cell protein was measured by the method of Bradford. ${ }^{22}$ )

Measurement of Labeling Index After $15 \mathrm{~h}$, the medium was replaced with hormone-free medium containing aprotinin $(1 \mu \mathrm{g} / \mathrm{ml})$, and various hormones were added. Bromodeoxyuridine (Amersham Corp., Arlington Heights, IL, U.S.A.) was included in the medium from 24 to $48 \mathrm{~h}$, and labeled nuclei were stained with anti-bromodeoxyuridine antibody according to the manufacturer's instructions.

Iodination of rh Activin A and Determination of Binding $\mathrm{rh}$ activin $\mathrm{A}(5 \mu \mathrm{g} / \mathrm{ml})$ was iodinated to a specific activity of approximately $10000 \mathrm{cpm} / \mathrm{ng}$ by the chloramine $\mathrm{T}$ method, as described previously. ${ }^{23,24)}$ Binding of $\left[{ }^{125} \mathrm{I}\right] \mathrm{rh}$ activin A to hepatocytes was measured by the modification of the method of Yasuda et al. ${ }^{14)}$ After $15 \mathrm{~h}$ of culture, hepatocytes were washed with $1 \mathrm{ml}$ of binding buffer containing $50 \mathrm{~mm}$ Hepes (pH 7.4), $128 \mathrm{~mm} \mathrm{NaCl}, 5 \mathrm{~mm} \mathrm{KCl}, 1.2 \mathrm{~mm}$ $\mathrm{CaCl}_{2}, 5 \mathrm{mM} \mathrm{MgSO}_{4}$, and $0.5 \% \mathrm{BSA}$, incubated with $0.6 \mathrm{ml}$ of the binding buffer for $30 \mathrm{~min}$ at $37^{\circ} \mathrm{C}$, and then cooled down to $4^{\circ} \mathrm{C}$. $\left.{ }^{125} \mathrm{I}\right] \mathrm{rh}$ activin $\mathrm{A}(25 \mathrm{ng} / \mathrm{ml})$ and various amounts of unlabeled activins were added to the hepatocytes, and after incubating them for $3.5 \mathrm{~h}$ at $4{ }^{\circ} \mathrm{C}$, and they were washed four times with $1 \mathrm{ml}$ of the ice-cold binding buffer and solubilized with $1 \mathrm{ml}$ of $1 \mathrm{~N} \mathrm{NaOH}$ for $1 \mathrm{~h}$ at $37^{\circ} \mathrm{C}$. Nonspecific binding determined in the presence of a 10-fold excess of unlabeled rh activin A was measured. Specific binding was defined as the difference between the total binding observed and the nonspecific binding. The differences between the total binding observed and the binding determined in the presence of various concentrations of activins were divided by the specific binding. Values are shown as percentages of $\left[{ }^{125} \mathrm{I}\right] \mathrm{rh}$ activin $\mathrm{A}$ bound.

\section{RESULTS}

Effect of Activins A, AB, and B on DNA Synthesis Stimulated by EGF Figure 1 shows the dose-dependence of the effect of activin $\mathrm{A}, \mathrm{AB}$, and $\mathrm{B}$ on DNA synthesis stimulated by EGF and assessed by $\left[{ }^{3} \mathrm{H}\right]$ thymidine incorporation. Activin $\mathrm{AB}$ at $6 \mathrm{ng} / \mathrm{ml}$ inhibited DNA synthesis, and almost maximal inhibition, approximately $40 \%$ inhibition was observed at $12.5 \mathrm{ng} / \mathrm{ml}$. Activin A also inhibited DNA synthesis, consistent with another report. ${ }^{14)}$ The inhibition by activin A was detected at $3 \mathrm{ng} / \mathrm{ml}$, and the inhibitory effect at $6 \mathrm{ng} / \mathrm{ml}$ was comparable to that of activin $\mathrm{AB}$ at $12.5 \mathrm{ng} / \mathrm{ml}$, although the extent of the maximal inhibition by activin $\mathrm{A}$ and activin $\mathrm{AB}$ was almost same. Activin $\mathrm{B}$, on the other hand, did not inhibit DNA synthesis up to $50 \mathrm{ng} / \mathrm{ml}$. The effect of these activins on DNA synthesis was also examined by nuclear labeling. As shown in Table 1, activin A and AB $(25 \mathrm{ng} / \mathrm{ml})$ inhibited the increase in nuclear labeling induced

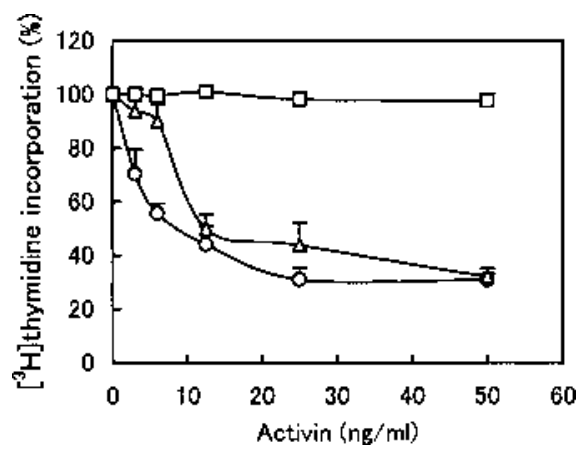

Fig. 1. Effect of Activins A, AB, and B on DNA Synthesis Stimulated by EGF

After $15 \mathrm{~h}$ culture, insulin $(0.1 \mathrm{nM}), \mathrm{EGF}(20 \mathrm{ng} / \mathrm{ml})$, and various concentrations of activins $\mathrm{A}(\mathrm{O}), \mathrm{AB}(\triangle)$, and $\mathrm{B}(\square)$ were added to the culture medium. Hepatocyte culture and the assay of DNA synthesis were performed as described in Materials and Methods. Values are means \pm S.D. of the percentage of $\left[{ }^{3} \mathrm{H}\right]$ thymidine incorporation in duplicate dishes in three experiments. $\left[{ }^{3} \mathrm{H}\right]$ thymidine incorporation in the presence and absence of insulin and EGF was approximately 700000 - 850000 and 80000-120000 $\mathrm{dpm} / \mathrm{mg}$ protein, respectively

Table 1. Effect of Activins A, AB and B on the Increase in Nuclear Labeling in Response to EGF

\begin{tabular}{ll}
\hline \hline Substance added & Nuclear labeling $(\%)$ \\
\hline None & $2.48 \pm 0.346$ \\
EGF & $18.8 \pm 0.759$ \\
EGF + activin A & $6.16 \pm 1.44$ \\
EGF + activin AB & $4.96 \pm 0.881$ \\
EGF + activin B & $18.1 \pm 1.37$
\end{tabular}

After $15 \mathrm{~h}$ culture, insulin $(0.1 \mathrm{nM})$, EGF $(20 \mathrm{ng} / \mathrm{ml})$, and activins $\mathrm{A}, \mathrm{AB}$, and $\mathrm{B}$ $(25 \mathrm{ng} / \mathrm{ml})$ were added to the culture medium. Hepatocyte culture and measurements of nuclear labeling were performed as described in Materials and Methods. Values are means \pm S.D. for duplicate dishes in three experiments.

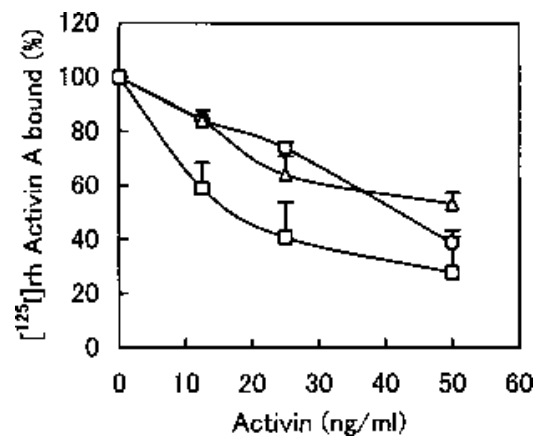

Fig. 2. Effect of Activins $\mathrm{A}, \mathrm{AB}$, and $\mathrm{B}$ on $\left[{ }^{125} \mathrm{I}\right] \mathrm{rh}$ Activin A Binding to Hepatocytes

After $15 \mathrm{~h}$ culture, hepatocytes were incubated with $\left[{ }^{125} \mathrm{I}\right] \mathrm{rh}$ activin $\mathrm{A}$ in the presence of various concentrations of unlabeled activins A $(O), \mathrm{AB}(\triangle)$ and B $(\square)$. Determination of binding was performed as described in Materials and Methods. Values are means \pm S.D. for duplicate dishes in three experiments. Specific binding of $\left[{ }^{125} \mathrm{I}\right] \mathrm{rh}$ activin A was approximately $2000 \mathrm{cpm} /$ plate.

by EGF. The extent of the inhibition by activin $\mathrm{A}$ and $\mathrm{AB}$ was almost same as shown by $\left[{ }^{3} \mathrm{H}\right]$ thymidine incorporation. Activin $\mathrm{B}$, on the other hand, had no effect on the increase in nuclear labeling. These findings are consistent with the results obtained by $\left[{ }^{3} \mathrm{H}\right]$ thymidine incorporation.

Effect of Activins A, AB, and B on $\left[{ }^{125} I\right]$ rh Activin A Binding to Hepatocytes Figure 2 shows the effect of activins $\mathrm{A}, \mathrm{AB}$, and $\mathrm{B}$ on the binding of $\left[{ }^{125} \mathrm{I}\right] \mathrm{rh}$ activin $\mathrm{A}$ to hepatocytes. $\left.{ }^{125} \mathrm{I}\right] \mathrm{rh}$ activin A binding was not only inhibited 


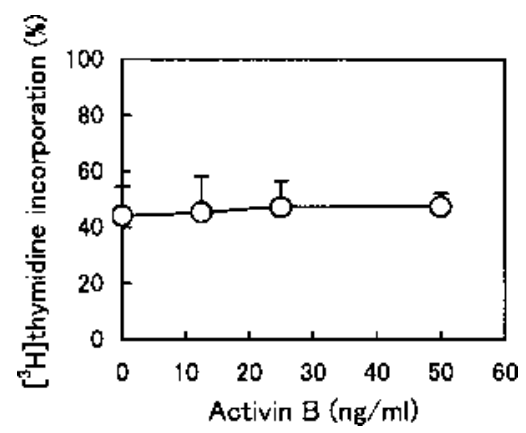

Fig. 3. Effect of Activin B on Inhibition of DNA Synthesis by Activin A

After $15 \mathrm{~h}$ culture, insulin $(0.1 \mathrm{nM}), \mathrm{EGF}(20 \mathrm{ng} / \mathrm{ml})$, activin A $(12.5 \mathrm{ng} / \mathrm{ml})$, and various concentrations of activin B were added to the culture medium. Hepatocyte culture and assay of DNA synthesis were performed as described in Materials and Methods. Values are means \pm S.D. and shown as percentages of $\left[{ }^{3} \mathrm{H}\right]$ thymidine incorporation in duplicate dishes in three experiments.

by activin $\mathrm{A}$ and $\mathrm{AB}$ in a dose-dependent manner, but by activin B as well. At concentrations below $25 \mathrm{ng} / \mathrm{ml}$ the extent of the inhibition by activin $B$ was even greater than by activin $\mathrm{A}$ and $\mathrm{AB}$.

Effect of Activin B on the Inhibition of DNA Synthesis by Activin A As shown in Fig. 3, activin B had no effect on the inhibition of DNA synthesis by activin A up to 3-fold excess concentrations.

\section{DISCUSSION}

The results of this study show that stimulation of DNA synthesis by EGF was inhibited by activin $\mathrm{AB}\left(\beta_{\mathrm{A}}, \beta_{\mathrm{B}}\right)$ as well as activin $\mathrm{A}\left(\beta_{\mathrm{A}}, \beta_{\mathrm{A}}\right)$, but not by activin $\mathrm{B}\left(\beta_{\mathrm{A}}, \beta_{\mathrm{B}}\right)$ (Fig. 1 , Table 1$)$. These results indicate that the $\beta_{\mathrm{A}}$ subunit is essential for inhibition of DNA synthesis by activins. Furthermore, the detailed dose-dependency study showed that the increase in $\beta_{\mathrm{A}}$ subunit in the composition of activin results in reduction of the effective concentration for inhibition, because activin A inhibited DNA synthesis at lower concentrations than activin AB. Since $\beta_{\mathrm{A}}$ mRNA was increased at $24 \mathrm{~h}$ in rat liver after partial hepatectomy and remained high for at least $72 \mathrm{~h},{ }^{14)}$ the $\beta_{\mathrm{A}}$ subunit seems to play an important role as a component of activin $\mathrm{A}$ and $\mathrm{AB}$ in the cessation of rat liver regeneration in vivo in the later phase.

There have been a few reports comparing the biological potency of activin $A$ with that of activins $A B$ and activin $B$. The $\mathrm{ED}_{50}$ values of activin $\mathrm{A}$ have been found to be almost same as those of activin AB in several assays, including stimulation of FSH secretion, FSH receptor expression and luteinizing horomone receptor expression. ${ }^{10)} \mathrm{The}^{\mathrm{E}} \mathrm{ED}_{50}$ value of activin $\mathrm{A}$ was also shown to be the same or about $25 \%$ lower than that of activin $\mathrm{AB}$ with regard to the induction of mouse erythroleukemia cell F5-5 differentiation. ${ }^{10,25)}$ Compared with these findings, the biological potency of activin A in our study was greater than that of activin $\mathrm{AB}$. The $\mathrm{ED}_{50}$ values of activin $B$, on the other hand, have been found to be about 5-fold higher than those of activin $\mathrm{A}$ and $\mathrm{AB}$ in these assays. ${ }^{10,25)}$ There is also a report that rh activin $B(40 \mathrm{ng} / \mathrm{ml})$ inhibits DNA synthesis by approximately 80 and $30 \%$, by human prostate tumor cell lines LNCaP and DU145 respectively. ${ }^{26)}$ The magnitude of the inhibitions was almost the same or the same as that of rh activin A, depending on the cell type. These findings conflict with the results of our study because activin B did not inhibit DNA synthesis even at 15fold the $\mathrm{ED}_{50}$ value of activin A (about $3 \mathrm{ng} / \mathrm{ml}$ ). The source of the activins used in this study was the same as in several other studies. ${ }^{10,25)}$ In the study using human prostate tumor cell lines, the effect of activin B was compared with that of activin A using the same recombinant human derived activins. $^{26)}$ Therefore, these differences are probably attributable to differences in the cell models used in the studies.

To elucidate the mechanism of the unresponsiveness to activin $\mathrm{B}$, we examined the effect of activin $\mathrm{B}$ on the binding of $\left[{ }^{125} \mathrm{I}\right] \mathrm{rh}$ activin $\mathrm{A}$ to hepatocytes. Our results showed that activin $B$ is more effective at inhibiting the binding of $\left[{ }^{125} \mathrm{I}\right] \mathrm{rh}$ activin A than activins A or AB (Fig. 2), indicating the presence of common receptors with a higher affinity for activin $\mathrm{B}$ than for activins A or AB. However, activin B did not have any effect on DNA synthesis or the inhibitory action of activin A (Figs. 1, 3, Table 1), suggesting that the common receptors do not mediate the signal transduction leading to the inhibition of DNA synthesis. Therefore, additional receptors that are specific to activins $\mathrm{A}$ and $\mathrm{AB}$ may be present and may be responsible for mediating the signal transduction. Zhang et al. reported the existence of two classes of binding sites having apparent $K_{\mathrm{d}}$ values of $3 \times 10^{-10}$ and $3.5 \times 10^{-9} \mathrm{M}$ in cultured rat hepatocytes. ${ }^{17)}$ They suggested that the highaffinity binding sites may represent an oligomeric complex of the type I and type II receptor and that at least part of the low affinity binding site may represent cell-bound follistatin. ${ }^{17)} \mathrm{A}$ preliminary dose-response study showed that $\left[{ }^{125} \mathrm{I}\right] \mathrm{rh}$ activin A binding was almost saturated at $25 \mathrm{ng} / \mathrm{ml}$, which is approximately equal to $1 \times 10^{-9} \mathrm{M}$ (data not shown). The $\mathrm{ED}_{50}$ value of rh activin A for inhibition of DNA synthesis was approximately $25 \mathrm{ng} / \mathrm{ml}$ (data not shown), and higher than that of porcine activin A. Based on this evidence, the common receptors seem to represent part of the oligomeric complex rather than cell-bound follistatin. Interestingly, multiple subtypes in both type I and type II receptor have been identified, ${ }^{27-30)}$ but the significance of this remains unclear. The specificity of receptor binding and the receptor-mediated signal transduction may depend on the subtype expressed in hepatocytes. Further study is required to clarify the mechanism of the inability of activin B to inhibit DNA synthesis, including characterization of common and specific receptors.

We recently found that the $\beta_{\mathrm{B}}$ mRNA level had increased at $1 \mathrm{~h}$ in the rat carbon tetrachloride model of liver regeneration, and that it peaked at $3 \mathrm{~h}$ and remained constant up to $24 \mathrm{~h}^{19)}$ This finding suggests that apart from the effects of activin B on DNA synthesis, activin B may play some other role in rat liver regeneration in vivo. Other possible regulatory activities of activin B include the modulation of hepatocyte mitogen levels, such as that of hepatocyte growth factor (HGF), which is synthesized in mesenchymal cells. ${ }^{31)}$ In fact, we found that activin B decreased the elevation of HGF protein levels produced by phorbol ester in MRC-5 human lung fibroblasts (Niimi, S., unpublished results). Therefore, activin $\mathrm{B}$ may suppress rat liver regeneration in vivo by decreasing the level of HGF.

\section{REFERENCES}

1) Hötten G., Neidhardt H., Schneider C., Pohl J., Biochem. Biophys. Res. Commun., 206, 608-613 (1995). 
2) Oda S., Nishimatsu S., Murakami K., Ueno N., Biochem. Biophys. Res. Commun., 210, 581-588 (1995).

3) Fang J., Yin W., Smiley E., Wang S. Q., Bonadio J., Biochem. Biophys. Res. Commun., 228, 669-674 (1996).

4) Lau A. L., Nishimori K., Matzuk M. M., Biochim. Biophys. Acta, 1307, 145-148 (1996).

5) Schmitt J., Hötten G., Jenkins N. A., Gilbert D. J., Copeland N. G., Pohl J., Schrewe H., Genomics, 32, 358-366 (1996).

6) Vale W., Rivier J., Vaughan J., McClintock R., Corrigan A., Woo W., Karr D., Spiess J., Nature (London), 321, 776-779 (1986).

7) Ling N., Ying S. Y., Ueno N., Shimasaki S., Esch F., Hotta M., Guillemin R., Biochem. Biophys. Res. Commun., 138, 1129-1137 (1986).

8) Ling N., Ying S. Y., Ueno N., Shimasaki S., Esch F., Hotta M., Guillemin R., Nature (London), 321, 779—782 (1986).

9) Mason A. J., Berkmeier L. M., Schmelzer C. H., Schwall R. H., Mol. Endocrinol., 3, 1352-1358 (1989).

10) Nakamura T., Asashima M., Eto Y., Takio K., Uchiyama H., Moriya N., Arizumi T., Yashiro T., Sugino K., Titani K., Sugino H., J. Biol. Chem., 267, 16385-16389 (1992).

11) Mellor S. L., Cranfield M., Ries R., Pederson J., Cancilla B., de Kretser D., Groome N. P., Mason A. J., Risbridger G. P., J. Clin. Endocrinol. Metab., 85, 4851-4858 (2000).

12) Mathews J. P., Moore A., Li R. H., Proc. Soc. Exp. Biol. Med., 215, 209-222 (1997).

13) Lebrun J. J., Chen Y., Vale W. W., "Inhibin, Activin and Follistatin, Regulatory Functions in System and Cell Biology," ed. by Aono T., Sugino H., Vale W. W., Springer-Verlag, NY, 1997, pp. 1-20.

14) Yasuda H., Mine T., Shibata H., Eto Y., Hasegawa Y., Takeuchi T., Asano S., Kojima I., J. Clin. Invest., 92, 1491-1496 (1993).

15) Schwall R. H., Robbins K., Jardieu P., Chang L., Lai C., Terrell T. G.,
Hepatology, 18, 347-356 (1993).

16) Hully J. R., Chang L., Schwall R. H., Widmer H. R., Terrell T. G., Gillett N. A., Hepatology, 20, 854-862 (1994).

17) Zhang Y. Q., Kanzaki M., Mashima H., Mine T., Kojima I., Hepatology, 23, 288-293 (1996).

18) Mine T., Kojima I., Ogata E., Endocrinology, 125, 586-591 (1989).

19) Kobayashi T., Niimi S., Hashimoto O., Hayakawa T., Biol. Pharm. Bull., 23, 755-757 (2000).

20) Tanaka K., Sato M., Tomita Y., Ichihara A., J. Biochem. (Tokyo), 84, 937-946 (1978).

21) Takai S., Nakamura T., Komi N., Ichihara A., J. Biochem. (Tokyo), 103, 848-852 (1988)

22) Bradford M. M., Anal. Biochem., 72, 248-254 (1976).

23) Hasegawa Y., Miyamoto K., Fukuda M., Takahashi Y., Igarashi M., Endocrinol. Jpn., 33, 645-654 (1986).

24) Hashimoto O., Nakamura T., Shoji H., Shimasaki S., Hayashi Y., Sugino H., J. Biol. Chem., 272, 13835-13842 (1997).

25) Uchiyama H., Asashima M., Biochem. Biophys. Res. Commun., 187, $347-352$ (1992).

26) McPherson S. J., Thomas T. Z., Wang H., Gurusinghe C. J., Risbridger G. P., J. Endocrinol., 154, 535-545 (1997).

27) Mathews L. S., Vale W. W., Cell, 65, 973-982 (1991).

28) Attisano L., Wrana J. L., Cheifetz S., Massague J., Cell, 68, 97-108 (1992).

29) Ethier J. F., Lussier J. G., Silversides D. W., Endocrinology, 138, 2425-2434 (1997).

30) Shoji H., Nakamura T., van den Eijnden-van Raaij A. J., Sugino H., Biochem. Biophys. Res. Commun., 246, 320-324 (1998).

31) Fausto N., Laird A. D., Webber E. M., FASEB J., 9, 1527-1536 (1995). 